\title{
Perceptions of Occupational Medicine Specialists on Suicide Prevention in the Workplace
}

\author{
Juliano de Trotta ${ }^{1}$, Sérgio C. Kowalski², Cláudia Lúcia Menegatti ${ }^{3}$, Francisco Cenci Comin ${ }^{1}$, \\ Plínio Cézar Neto ${ }^{1} \&$ e Marina Rachid Barreto ${ }^{4}$ \\ ${ }^{1}$ Pontifical Catholic University of Paraná, School of Medicine, Curitiba, Paraná, Brazil \\ ${ }^{2}$ Federal University of Paraná, Department of Internal Medicine, Curitiba, Paraná, Brazil \\ ${ }^{3}$ Pontifical Catholic University of Paraná, Department of Psychology, Curitiba, Paraná, Brazil \\ ${ }^{4}$ Little Prince College, Medicine College, Curitiba, Paraná, Brazil \\ Correspondence: Juliano de Trotta, School of Medicine, Pontifical Catholic University of Paraná, Curitiba, PR., \\ Brazil. Tel: 55-(41)-99501-9502.
}

Received: January 8, 2021 Accepted: April 3, 2021 Online Published: April 13, 2021

doi:10.5539/gjhs.v13n5p81 URL: https://doi.org/10.5539/gjhs.v13n5p81

\begin{abstract}
Suicide rates have taken on alarming dimensions with catastrophic consequences. This study aims to understand the perceptions of occupational medicine specialists about suicide prevention and describe what actions work organizations are taking to prevent suicide among their workers. This is an exploratory, cross-sectional, descriptive, quantitative study, carried out with 24 occupational medicine specialists with experience in workers' mental health, using online forms. The analyses were performed using Excel and SPSS software. In the results, the indicators that most appeared among specialists as prevalent in the development of controls for suicide risk were: (1) to control the reasons for social security leaves $(n=23,95.8 \%)$; (2) to train leaders for people management $(n=23,95.8 \%)$; and (3) to have an official means of communication within the company to report violence at work ( $\mathrm{n}=20,83.3 \%)$. There were 42 recommendations described by the specialists. They were grouped into 8 categories and are part of 4 different dimensions of suicide prevention. Suicide is a complex phenomenon of multifactorial nature, which involves all the dimensions of life and influences the people close to it directly and indirectly. Therefore, there is no single way to approach this issue in work organizations, nor a single way to promote prevention, given the fact that the practical experiences of the physicians expand the approach of health services.
\end{abstract}

Keywords: mental health, health program, suicide, prevention of mental disorders at work

\section{Introduction}

According to the World Health Organization [WHO] (2014), there were more than 800,000 cases of suicide on the planet in 2012. However, the WHO believes that this figure is underestimated about 20 times due to the lack of notifications and data from countries in the Middle East and Africa. Thus, it is estimated that there is one death by suicide every 40 seconds and one attempted self-harm every two seconds in the world, with consequences that are not restricted only to the victim, but that cause severe emotional, social and economic repercussions in at least six people close to the deceased (WHO, 2014; Junior, 2015).

With the increase of $60 \%$ in suicide cases in the last 50 years, the average number of suicides was 10.5 deaths per 100,000 inhabitants worldwide in 2016 (WHO, 2020). In Brazil, the average suicide rate was 5.2 per 100 thousand inhabitants every year between 2010 and 2014 (Dantas et al., 2018).

The French sociologist, philosopher, psychologist Émile Durkheim, in the $19^{\text {th }}$ century, has conceptualized suicide as "all cases of death resulting directly or indirectly from a positive or negative act of the victim himself, which he knows will produce this result", bringing this concept as a social phenomenon provided by a modern pathological society (Durkheim, 1982/2014).

The American psychologist Edwin Shneidman, in the $21^{\text {st }}$ century, brought the conception that suicide was a product of the confluence of the limits of: psychological pain, cognitive perturbation and the pressure from life events, which can be strong indications in the search for suicidal behavior at the collective workplace (Shneidman, 1969). 
Christophe Dejours, who is another scholar on this subject, mentions that the transformation of management processes, with the individual assessment of worker productivity, the requirement for total quality and the outsorcing of labor has generated drastic consequences for mental health's workers, opening a field to moral harassment, lack of solidarity and worker despair, which may lead to suicide (Dejours \& Bègue, 2010).

WHO studies show a deficiency in case-control, care, and prevention actions by mental health policies. Moreover, there is no adequate relationship between supply and demand for mental disorders treatment (WHO, 2012). In 2018 , only 28 of the 194 WHO member states reported maintaining any measure of suicide prevention at a national level (WHO, 2018).

Suicide in the workplace is a complex and multifactorial theme, however it is a predictable cause of death, liable to intervention. The indicators of suicidal behavior are always present and must be identified early. The actions in suicide prevention must be linked to combating the vulnerability of the work organization, and adapted to the place where these actions will be carried out (Benatov et al., 2020; Platt \& Niederkrotenthaler, 2020; Yip et al., 2010).

This study aims to understand the perceptions and experiences of occupational medicine specialists about suicide prevention in the workplace and describe what work organizations are doing to prevent suicide.

\section{Method}

This is an exploratory, cross-sectional, descriptive, quantitative study and is part of a wider research on suicide prevention at work.

An online survey was conducted using the SurveyMonkey ${ }^{\circledR}$ platform, consisting of both objective and open-ended questions. Thirty-two specialists, who were selected considering their fields of work and experiences with the topic, were sent a link to the survey. The sample was composed of working physicians who are from various regions of Brazil and have expertise in mental health and suicide prevention.

The questionnaire was designed to be an objective instrument, composed by similar items that can be related to each other. Therefore, it contributes to the formation of a reliable result, bringing internal consistency to the specialists' answers.

The sample was composed of non-probability technique, snowball sampling. The initial respondents were the manager doctors who are part of the author's contacts. They were selected due to the degree of the specialization required from the respondents. It has known that a saturation of information from a certain number of respondents is a possible outcome (Small, 2009). Ben Baumberg, from the University of Kent at Canterbury, describes that after about 25 interviews, he found the same phenomena repeatedly (Baker \& Edwards, 2012). Others authors refer that, in these conditions, sometimes it is difficult to consider more than ten participants (Flick, 2008).

The answers provided by the specialists were transposed and descriptively analyzed using the Microsoft Office Excel ${ }^{\circledR}$ software and Surveymonkey ${ }^{\circledR}$ tabulations. The random variables were analyzed using the SPSS software. The Shapiro-Wilk test showed a non-parametric pattern with $\mathrm{p}<0.01$. For the comparative variables, the Cochran $\mathrm{Q}$ test and the Wilcoxon test were used.

The inclusion criteria were: (1) being an occupational physician, (2) having knowledge about mental health or suicide prevention programs, and (3) being voluntary and agreeing to sign the free consent form.

The exclusion criteria were the occupational physicians who declared having no experience or contact with mental health programs at work.

This study is part of a wider research on suicide prevention, which was planned and approved by the ethics committee under the CAAE number: 13106719.2.0000.0102.

\section{Results}

Thirty-two physicians who complied with the inclusion criteria were asked to participate, of which 24 (75\%) answered the questionnaire.

Most doctors are internally hired $(\mathrm{n}=15,62.5 \%)$, from large $(\mathrm{n}=17,70.8 \%)$, multinational companies $(\mathrm{n}=13$, $54.2 \%)$, with a degree of risk three $(n=16,66.7 \%)($ Table 1$)$. 
Table 1. Participants' workplace characteristics

\begin{tabular}{|c|c|c|}
\hline Work characteristics & $\mathrm{n}$ & $\%$ \\
\hline \multicolumn{3}{|l|}{ Main activity of the Physician } \\
\hline Occupational physicians hired directly by the company & 15 & 62.5 \\
\hline External occupational physicians, occupational medicine service provider & 4 & 16.7 \\
\hline Public service occupational physicians & 2 & 8.3 \\
\hline Physicians working in clinics hospitals & 2 & 8.3 \\
\hline Professor & 1 & 4.2 \\
\hline \multicolumn{3}{|l|}{ Company size } \\
\hline Microenterprise & 0 & 0.0 \\
\hline Small & 1 & 4.2 \\
\hline Medium & 2 & 8.3 \\
\hline Big & 17 & 70.8 \\
\hline Do not work in companies & 4 & 16.7 \\
\hline \multicolumn{3}{|l|}{ Company nationality } \\
\hline Brazilian & 8 & 33.3 \\
\hline Swedish & 2 & 8.3 \\
\hline North American & 4 & 16.7 \\
\hline Spanish & 1 & 4.2 \\
\hline Australian & 1 & 4.2 \\
\hline German & 2 & 8.3 \\
\hline Japanese & 1 & 4.2 \\
\hline English & 1 & 4.2 \\
\hline European Union & 1 & 4.2 \\
\hline Do not work in companies & 3 & 12.5 \\
\hline \multicolumn{3}{|l|}{ Degree of risk of the company } \\
\hline Grade 1 & 1 & 4.2 \\
\hline Grade 2 & 2 & 8.3 \\
\hline Grade 3 & 16 & 66.7 \\
\hline Grade 4 & 1 & 4.2 \\
\hline Does not apply & 4 & 16.7 \\
\hline
\end{tabular}

Source: The author, 2021.

Of the physicians surveyed, twelve $(50 \%)$ reported that there is currently a mental health or suicide prevention program in the companies they work for or provide some type of occupational medicine service to. Thirteen $(54.2 \%)$ said that the work organizations they were part of took some specific suicide prevention actions in the past three years. According to the Wilcoxon test $(Z=-1.265 ; p=0.206)$, there is no significant difference between the two variables.

When asked about factors and actions that can help understand and control the risk of suicide among workers, the following indicators were mentioned by the specialists: (a) absenteeism control by ICD (International Classification of Diseases) $(n=21,87.5 \%)$; (b) to control the reasons for illness due to social security leaves $(n=$ $23,95.8 \%$ ); (c) to have an official means of communication within the company that can be used by any employee to report moral, sexual or any other type of harassment or violence at work $(n=20,83.3 \%)$; (d) to prepare and train leaders for people management ( $\mathrm{n}=23,95.8 \%)$; (e) training the medical outpatient clinic team to care for patients at risk of suicide $(\mathrm{n}=12,50 \%)$; (f) to promote a pre-determined flow to assist chemical dependent workers $(\mathrm{n}=16$, 
66.7\%); and some respondents also reported that they had in their ergonomic assessment of the workplace the presence of cognitive and organizational analysis (in addition to physical ergonomics) $(n=8,33.3 \%)$.

The benefits companies offered to improve workers' quality of life and promote the care for their mental health are presented in Table 2. The chi-square test showed that the offer of the following benefits by companies is statistically lower $(\mathrm{p}<0.001)$ in comparison with other benefits provided by the companies described in Table 2: (1) presence of a social worker, (2) an internal psychologist, (3) offering voluntary services, and (4) having an adequate method for "feedback".

Table 2. Benefits of companies that influence workers' quality of life

\begin{tabular}{lcc}
\hline Benefits & Yes & \% \\
\hline Clinical Nutritionist for individual employee care & 11 & 45.8 \\
Agreements with gyms or other sports facilities, provided by the company & 15 & 62.5 \\
Incentive for employee instruction & 21 & 58.3 \\
Health insurance plan & 18 & 87.5 \\
Dental insurance plan & 13 & 75 \\
Collective transportation provided by the company & 16 & 54.2 \\
Restaurant in the company & 8 & 66.7 \\
Internal clinical psychologist in the company & 16 & 33.3 \\
The health insurance plan provides a psychologist & 8 & 66.7 \\
There is a social worker as support in the clinic & 13 & 33.3 \\
The worker has the freedom to take breaks when necessary & 9 & 54.2 \\
There is a "feedback" methodology for workers & 11 & 37.5 \\
There is a place for the workers to rest & 9 & 45.8 \\
Voluntary service offer & & 37.5
\end{tabular}

Source: The author, 2021.

According to the evaluation of specialist physicians, using a scale from 0 to 10 , suicide prevention actions or programs in work organizations are of great importance (median of 9 points). However, the doctors with a similar grade evaluation, bordering a median of 6 points, declared difficulties in prioritizing these actions in their routines inside their work organizations. This is probably due to the theme's complexity and subjectivity, the time it takes, and the work organizations' concerns in addressing this issue.

Most physicians ( $\mathrm{n}=18,81.8 \%$ ) had the experience of assisting or having knowledge, in their respective companies, of 30 cases of suicide or attempted suicide by direct employees (Table 3 ).

Table 3. Doctors' knowledge reports about cases of suicide attempt (SA) or suicide

\begin{tabular}{lcc}
\hline Assisted or knew of any case of suicide or SA in the company & Yes & $\%$ \\
\hline The employee committed suicide and it occurred inside the company & 2 & 8.3 \\
The employee committed suicide, but it occurred outside the company & 9 & 37.5 \\
The employee attempted suicide and it occurred inside the company & 15 & 16.7 \\
The employee attempted suicide, but it occurred outside the company & 6 & 62.5 \\
A family member of an employee committed suicide & 3 & 25.0 \\
A family member of an employee attempted suicide & 3 & 12.5 \\
I do not know of a suicide case or suicide attempt & 12.5 \\
\hline
\end{tabular}

Source: The author, 2021 
Some companies have security measures that ultimately obstruct access to situations that may cause insult, injury, or death in the work environment. These could become protective actions in the prevention of suicide (Table 4).

Table 4. Protective actions of companies restricting access to means of suicide or self-harm in their facilities

\begin{tabular}{lcc}
\hline Protective actions of companies & Yes & $\%$ \\
\hline Protection in the access to high open spaces & 6 & 25.0 \\
Prohibition of sharp knives in common areas & 4 & 16.7 \\
Application of window restrictors & 0 & 0.0 \\
Control of hazardous substances & 10 & 41.7 \\
Formal rules against carrying weapons inside the company & 12 & 50.0 \\
I do not know any action in this regard & 9 & 37.5 \\
\hline
\end{tabular}

Source: The author, 2021.

Finally, through an open-ended question, the specialists were asked what variables of influence can help to understand, prevent or reduce the risk of suicide among workers. In addition, they were questioned about possible suggestions for action. There were 42 recommendations. The answers were grouped into four main dimensions.

The first dimension brought 10 suggestions from specialists on ways to act in the prevention of suicide in their respective companies (Chart 1).

Chart 1. Description of the training dimension, which includes training, guidance, clarification of workers

\begin{tabular}{|c|c|c|c|c|}
\hline \multicolumn{2}{|c|}{ Dimensions } & \multirow{2}{*}{$\begin{array}{l}\text { Categorical subdivisions } \\
\text { Training of health care staff to provide } \\
\text { adequate shelter to workers at risk of suicide }\end{array}$} & \multirow{2}{*}{$\begin{array}{l}\text { Quantity } \\
1\end{array}$} & \multirow{2}{*}{$\begin{array}{l}\text { Specialists' opinions } \\
\text { "to recognize some signs that } \\
\text { identify a potential suicide" }\end{array}$} \\
\hline & \multirow{10}{*}{$\begin{array}{l}\text { Training (training, } \\
\text { guidance, clarifications) }\end{array}$} & & & \\
\hline & & \multirow{5}{*}{ Training leaders on issues related to suicide } & \multirow{5}{*}{5} & "leaders' awareness" \\
\hline & & & & $\begin{array}{l}\text { "leaders closer to the people and } \\
\text { especially to the operational sector" }\end{array}$ \\
\hline & & & & "management training" \\
\hline & & & & $\begin{array}{l}\text { "training leaders to perceive } \\
\text { behavior changes" }\end{array}$ \\
\hline & & & & "training leaders about harassment" \\
\hline & & \multirow{4}{*}{$\begin{array}{l}\text { Orientative communication actions for } \\
\text { employees on the theme }\end{array}$} & & "to talk about the topic" \\
\hline & & & & "employee training" \\
\hline & & & & $\begin{array}{l}\text { "lectures with a mental health } \\
\text { professional" }\end{array}$ \\
\hline & & & & $\begin{array}{l}\text { "lectures and videos on suicide and } \\
\text { other mental disorders" }\end{array}$ \\
\hline
\end{tabular}

Source: The author, 2021.

The second dimension was the one that received the highest number of intervention recommendations: 21 (50\%) of the 42 suggested. This dimension refers to the "care and conduct of the medical team" and are composed of the categories: identification and control of mental disorders, fighting substance dependence, and flow of multidisciplinary care to support patients at risk of suicide (Chart 2). 
Chart 2. Description of the dimension of care and conduct of the medical team, which includes control of mental illnesses, chemical dependency and workflow of care

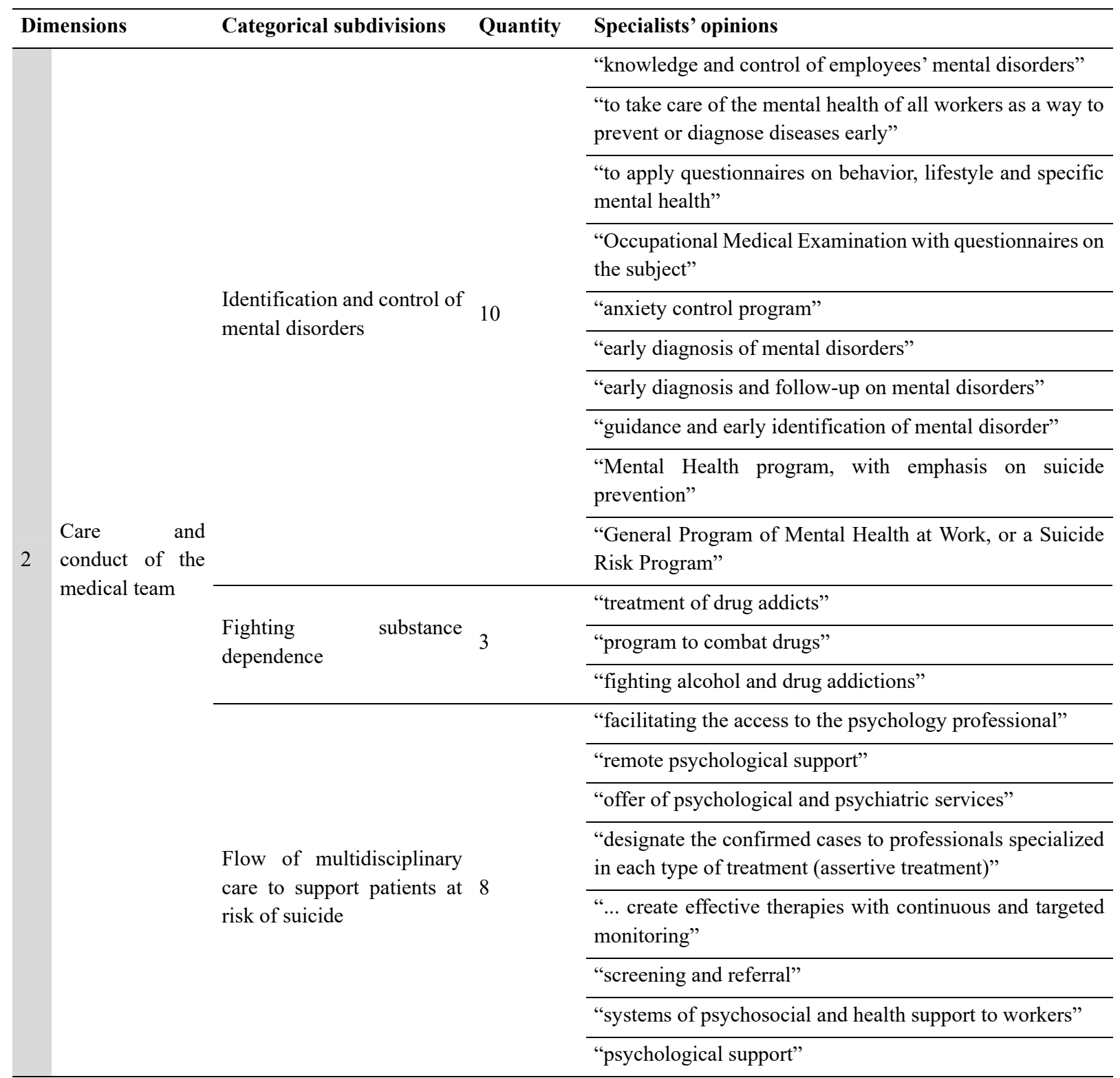

Source: The author, 2021.

The third and fourth dimensions were the ones that received the lowest number of recommendations from specialists, with three and eight suggestions, respectively. The descriptions of these dimensions are represented in Chart 3. 
Chart 3. Description of dimensions three and four, which include freedom of expression for the worker and the promotion of coping mechanisms

\begin{tabular}{|c|c|c|c|c|}
\hline \multicolumn{2}{|c|}{ Dimensions } & \multirow{4}{*}{$\begin{array}{l}\text { Categorical subdivisions } \\
\text { Confidential } \\
\text { communication channel for } \\
\text { workplace violence }\end{array}$} & \multirow{4}{*}{$\begin{array}{l}\text { Quantity } \\
3\end{array}$} & \multirow{3}{*}{$\begin{array}{l}\text { Specialists' opinions } \\
\text { "to offer channels of communication and support" } \\
\text { "... to expose your personal or professional problems in a } \\
\text { confidential and safe way..." }\end{array}$} \\
\hline \multirow{3}{*}{3} & \multirow{3}{*}{$\begin{array}{l}\text { Freedom } \\
\text { speech }\end{array}$} & & & \\
\hline & & & & \\
\hline & & & & "a safe space for the employees to express their anxieties" \\
\hline \multirow{8}{*}{4} & \multirow{8}{*}{$\begin{array}{l}\text { Promotion of } \\
\text { workers' coping } \\
\text { mechanisms }\end{array}$} & \multirow{8}{*}{ Personal development } & \multirow{8}{*}{8} & "self-awareness and management of emotions" \\
\hline & & & & $\begin{array}{l}\text { "mapping of risk factors for the development of } \\
\text { psychosocial pathologies" }\end{array}$ \\
\hline & & & & "Cíngulo APP" \\
\hline & & & & $\begin{array}{l}\text { "to stimulate the development of employees' coping } \\
\text { mechanisms" }\end{array}$ \\
\hline & & & & $\begin{array}{l}\text { "stimulus from the company to the workers' coping } \\
\text { mechanisms" }\end{array}$ \\
\hline & & & & "openness for constructive interpersonal contacts" \\
\hline & & & & "HR programs for personal motivation and construction" \\
\hline & & & & "work on prevention through self-care guidelines" \\
\hline
\end{tabular}

Source: The author, 2021.

The dimensions bring the frequency of the specialists' recommendations of actions and reflect the importance of these actions in their respective work organizations. It represents a direct intervention in the health area, approaching the control, management and treatment of diseases.

\section{Discussion}

Many actions and perceptions brought by the specialists are part of the WHO recommendations (Botega, 2015). This approximation validates and enriches the results presented in this study because they showed, in more detail, the practical way of acting with these guidelines in the field of work.

The indicators most mentioned by specialists as prevalent in the development of actions to control the risk of suicide were: (1) controlling the reasons for social security leaves; (2) training leaders on people management - 23 of the 24 surveyed, that is, $95.8 \%$ cited these items; (3) 20 (83.3\%) reported the need to have an official means of communication within the company to report workplace violence. According to the physicians, these were the most important means of identifying suicide risk in the companies.

The control of social security leaves is important in Brazil. These are longer work leaves - when the disability lasts longer than 15 days - that cause significant impacts on both the patient and the work organization. In this scenario, by listing the number of absences due to the disease through the ICD (International Classification of Diseases), especially concerning mental disorders and substance dependence (Group F), one can have the panorama of the mental health of both the individual and the company as a whole. This measure enables the professionals to outline control and follow-up strategies so that disastrous consequences - such as suicide - do not occur.

According to several studies, mental disorders, substance dependence, and history of attempts against one's own life in the past add up as the main risk factors for suicide (Bennett, Coggan, \& Addams, 2003; Bertolote \& Fleischmann, 2004; Costa et al., 2014; Holmes \& Holmes, 2014; Shah, Bhandarkar, \& Bhatia, 2010; Silveira, Fidalgo, Di Pietro, Santos, \& Oliveira, 2014; Doupnik et al., 2020), making the early identification of this group one of the main actions in the fight against suicide (WHO, 2014).

Tied to the previous point in the perceptions of the specialists, the training of leadership for people management, especially with regard to instruction in the identification of colleagues suffering and in combating bullying, provides the reception and early referral to professionals of competence, reducing the risk of mental disorder and suicide (Suicide Prevention Resource Center, 2013). 
The internal communication channel for denouncing violence at work has its strong point in that it allows us to understand the phenomena both quantitatively (by the number of reports per department or locality) and qualitatively (investigating the content of the reports of possible cases of harassment that workers may be suffering). According to Christophe Dejours (2009), harassment at work is an old theme that sometimes results from increased work demands. However, today it occurs because of the lack of solidarity in the work environment (Dejours, 2009; Freitas, 2011; Terpstra et al., 2018; Milner, Page, Witt, \& Lamontagne, 2016; Knox et al., 2010; Goldman \& Schmalz, 2003; Carreiro, 2007; Soboll \& Glima, 2012).

Although the notes of indicators and variables of influence in relation to the mental health and risk of suicide of the workers mentioned by the specialists are not forms of prevention per se, they represent the visible part of a larger problem. In turn, this problem needs to be understood and treated strategically within work organizations so they do not perpetuate ethical deviations or neglect diseases and their consequences (Dejours, 2018).

As previously described, the 42 suggestions of the specialists raised through the survey with a descriptive questioning about the influencing variables that can help to understand, reduce or prevent suicides among workers were grouped into 8 categories that belong to 4 major dimensions of performance. The prevailing ones were: (1) control of mental disorders, with 10 citations $(23.8 \%)$ and $8(19 \%)$ recommendations each: (2) pre-established flow of multidisciplinary care to support patients in need (3) promotion of workers' coping mechanisms, among others that can be seen in Chart 1 .

The control of mental disorders appeared again in the specialists' descriptive responses. This result aligns with the literature since psychiatric disorders increase suicide and suicide attempt cases more than 10 times compared to the general population. According to statistics, between $60 \%$ and $98 \%$ of suicides are committed by psychiatric patients (Bertolote \& Fleischmann, 2002; Bertolote, Fleischmann, De Leo, \& Wasserman, 2004; Chang, Gitlin, \& Patel, 2011; Ferrari et al., 2014; Röcker \& Bachmann, 2015). This data portrays the relevance of addressing this dimension in mental health and suicide prevention programs.

The benefits provided by the work organizations most cited by the interviewed physicians were the presence of a health insurance plan $(n=21,87.5 \%)$, a dental insurance plan $(n=18,75 \%)$, internal restaurant $(n=16,66.7 \%)$, and the possibility of consulting with an external psychologist, among others cited in table 2 .

These corporate benefits ultimately improve the worker's quality of life and strengthen their means of coping with adversity, mitigating the psychosocial risk factors of the workers and their families (Wang, Chou, Yeh, Chen, \& Tzeng, 2013).

On the other hand, nine (37.5\%) physicians were unaware of structural safety actions or rules of conduct adopted by companies. The application of window restrictors, restriction of access to elevated spaces and dangerous chemicals, or prohibition of weapons inside companies may hinder actions of violence or self-aggression within work organizations, also becoming protective actions in the prevention of suicide cited in other studies (houtsma, Butterworth, \& Anestis, 2013; Martelli, Awad, \& Hardy, 2010).

The WHO (2014) states that suicide is preventable and advises that institutions limit access to firearms and dangerous chemicals - which are the most used methods to execute suicide - as one of the prevention strategies (Platt \& Niederkrotenthaler, 2020; WHO, 2014).

According to Botega (2015), one can only evaluate the risk of suicide if this possibility is considered, i.e., when one notices that people close to them may be going through chronic suffering for various reasons, hiding their feelings due to shame or fear of losing their job, and be at risk of suicide (Botega, 2015). The WHO recommends that the prevention of suicide, through known dimensions, be one of the central axes of health care services (WHO, 2014).

\section{Conclusion}

Suicide is a serious global public health problem, with social, economic, and political consequences. Individualized preventive approaches, such as undergoing psychotherapy, taking medications, and referring workers to specific treatments, are not enough. According to the specialists interviewed, multidisciplinary actions involving the vulnerable people, the risk situations, and the patient's social network are important starting points to encourage managers to intervene and combat self-harm in work organizations.

Finally, as previously described, suicide is a complex multifactorial phenomenon, which involves all dimensions of life and influences people close to it directly and indirectly. Therefore, there is no single way to approach this issue in work organizations, nor a single way to promote prevention. Because it can be preventable, suicide at work is a brutal message to the work community, leaders, colleagues, subordinates, and the company in general, but this 
message must be decoded before it happens (Dejours \& Bègue, 2010).

This study brings the experiences of occupational physicians with the prevention of self-harm. Even with a small sample, it is able to promote reflections on what medical managers do in their institutions and the degree of importance they bring to their perceptions. Thus, each person, within their reality, the circumstances of their patient, and the company's possibilities, can adapt the content presented here to their daily practice to prevent suicide among workers.

\section{Competing Interests Statement}

The authors declare that there are no conflicts of interest in this study and that there were no funding sources for this research.

\section{References}

Baker, S. E., \& Edwards, R. (2012). How many qualitative interviews is enough. Nature Centre Research Methods Review Paper, p. 37, Retrieved from: https://www.researchgate.net/publication/277858477_How_many_qualitative_interviews_is_enough

Benatov, J., Klomek, A. B., Shira, B., Apter, A., Carli, V., \& Wasserman, C. (2020). Doing Nothing is Sometimes Worse: Comparing Avoidant versus Approach Coping Strategies with Peer Victimization and Their Association to Depression and Suicide Ideation. Journal of School Violence, 19(4), 456-469. https://doi.org/10.1080/15388220.2020.1738941

Bennett, S., Coggan, C., \& Adams, P. (2003). Problematising depression: young people, mental health and suicidal behaviours. Social Science \& Medicine, 57(2), 289-299. https://doi.org/10.1016/S0277-9536(02)00347-7

Bertolote, J. M., \& Fleischmann, A. (2002). A global perspective in the epidemiology of suicide. Suicidology, 7(2), 6-8. https://doi.org/10.5617/suicidologi.2330.

Bertolote, J. M., \& Fleischmann, A. (2004). Suicídio e doença mental: uma perspectiva global. In B. S. G. Werlang \& N. J. Botega (Eds.), Comportamento suicida (pp. 35-44). Porto Alegre: Artmed.

Bertolote, J. M., Fleischmann, A., De Leo, D., \& Wasserman, D. (2004). Psychiatric diagnoses and suicide: Revisiting the evidence. Crisis, 25, 147-155. https://doi.org/10.1027/0227-5910.25.4.147.

Botega, N. J. (2015). Crise suicida: avaliação e manejo. Porto Alegre: Artmed.

Carreiro, L. M. (2007). Morte por excesso de trabalho (Karoshi). Revista do Tribunal Regional do Trabalho da $3^{a}$ Região, Belo Horizonte, MG, 46(76), 131-141.

Chang, B., Gitlin, D., \& Patel, R. (2011). The depressed patient and suicidal patient in the emergency department: Evidence-based management and treatment strategies. Emergency Medicine Practice, 13, 23-24.

Costa, L. D. S., Alencar, A. P., Neto, P. J. N., Santos, M. D. S. V. D., da Silva, C. G. L., Pinheiro, S. D. F. L., ... \& Neto, M. L. R. (2014). Risk factors for suicide in bipolar disorder: A systematic review. Journal of Affective Disorders, 170C, 237-254. https://doi.org/10.1016/j. jad.2014.09.003

Dantas, A. P., Azevedo, U. M., Nunes, A. D., Amador, A. E., Marques, M. V., \& Barbosa, I. R. (2018). Analysis of suicide mortality in Brazil: spatial distribution and socioeconomic context. Revista Brasileira de Psiquiatria, 40(1), 12-18. https://doi.org/10.1590/1516-4446-2017-2241

Dejours, C. (2009). A loucura do Trabalho: estudo de psicopatologia do trabalho (5th ed.). Ampliada. São Paulo: Cortez-Oboré, 1992 e 17.

Dejours, C. (2018). Reflexões do psicanalista francês Christophe Dejours sobre o assédio moral no trabalho. Jornal Estado do Paraná, Retrieved fromhttp://estadodedireito.com.br/reflexoes_do_psicanalista_frances_christophe_dejours_sobre_assedio_m oral/

Dejours, C., \& Bègue, F. (2010). Suicídio e trabalho: o que fazer? Sobradinho (DF): Paralelo 15.

Doupnik, S. K., Rudd, B., Schmutte, T., Worsley, D., Bowden, C. F., McCarthy, E., ... \& Marcus, S. C. (2020). Association of suicide prevetaion interventions with subsequent suicide attempts, linkage to follow-up care, and depression symptoms for acute care settings: A systematic review and meta-analysis. JAMA Psychiatry, 77(10), 1021-1030.

Durkheim, E. (1982/2014). O Suicídio - Um Estudo Sociológico. Rio de Janeiro: Zahar Editores.

Ferrari, A. J., Norman, R. E., Freedman, G., Baxter, A. J., Pirkis, J. E., Harris, M. G., ... \& Vos, T. (2014). The 
burden attributable to mental and substance use disorders as risk factors for suicide: Findings from the Global Burden of Disease Study 2010. PLoS ONE, 9, e91936. https://doi.org/10.1371/journal.pone.0091936

Flick, U. (2008) Designing Qualitative Research Book 1 of The SAGE Qualitative Research Kit. London/ Thousand Oaks, CA: Dehli: Sage.

Freitas, M. E. D. (2011). Suicídio, um problema organizacional. GV Executivo, 10(1), 54-57.

Goldman, K. D., \& Schmalz, K. J. (2013). "I gave at the office," but did I give enough? Handling traumatic events. Health Promotion Practice, 4(1), 5-7.

Holmes, C. R. M., \& Holmes, S. T. (2014). Drugs, Alcohol and Suicide. In: Suicide: Theory, Practice, and Investigation Depression (pp. 127-139). Thousand Oaks, CA: SAGE Publications, Inc.

Houtsma, C., Butterworth, S. E., \& Anestis, M. D. (2018). Firearm suicide: pathways to risk and methods of prevention. Current Opinion in Psychology, 22, 7-11.

Junior, A. F. (2015). O comportamento suicida no Brasil e no mundo. Revista Brasileira de Psicologia, 2(01), Salvador, Bahia.

Knox, K. L., Pflanz, S., Talcott, G. W., Campise, R. L., Lavigne, J. E., Bajorska, A., ... \& Caine, E. D. (2010). The US Air Force Suicide Prevention Program: Implications for Public Health Policy. American Journal of Public Health, 100(12), 2457-2463. https://doi.org/10.2105/AJPH.2009.159871

Martelli, C., Awad, H., \& Hardy, P. (2010). In-patients suicide: Epidemiology and prevention. Encephale, 36(2), 83-91. https://doi.org/10.1016/j.encep.2009.06.011

Milner, A., Page, K., Witt, K., \& Lamontagne, A. (2016). Psychosocial Working Conditions and Suicide Ideation: Evidence from a Cross-Sectional Survey of Working Australians. Journal of Occupational and Environmental Medicine, 58(6), 584-587. https://doi.org/10.1097/JOM.0000000000000700

Platt, S., \& Niederkrotenthaler, T. (2020). Suicide prevention programs: Evidence base and best practice. Crisis, 41(1), 99-124. http://doi.org/10.1027/0227-5910/a000671

Röcker, S., \& Bachmann, S. (2015). Suicidality in mental illness-Prevention and therapy. Therapeutische Umschau, 72, 611-617. https://doi.org/10.1024/0040-5930/a000727

Shah, A., Bhandarkar, R., \& Bhatia, G. (2010). The relationship between general population suicide rates and mental health funding, service provision and national policy: a cross-national study. The International Journal of Social Psychiatry, 56(4), 448-453. https://doi.org/10.1177/0020764009342384

Shneidman, E. S. (1969). Suicide, lethality, and the psychological autopsy. International Psychiatry Clinics, 6(2), 225-250. Retrieved from https://europepmc.org/article/med/5810563

Silveira, D. X. D. A, Fidalgo, T. M., Di Pietro, M., Santos Jr, J. G., \& Oliveira, L. Q. (2014). Is Drug Use Related to the Choice of Potentially More Harmful Methods in Suicide Attempts? Substance Abuse: Research and Treatment, 8, 41-43. https://doi.org/10.4137/SART.S13851

Small, M. L. (2009). How many cases do I need? On science and the logic of case selection in field-based research, Ethnography, 10(10), 5-38.

Soboll, L. A. P., \& Glima, D. N. R. (2012). Intervenções em assédio moral no trabalho: uma revisão da literatura. Revista Brasileira de Saúde Ocupacional, 37(126), 269-283.

Suicide Prevention Resource Center. (2013). The Role of Co-Workers in Preventing Suicide in the Workplace. February, Retrieved

from https://www.iasp.info/pdf/special_interest_groups/workplace/coworkers_suicide_prevention.pdf_

Terpstra, S., Beekman, A., Abbing, J., Jaken, S., Steendam, M., \& Gilissen, R. (2018). Suicide prevention gatekeeper raining in the Netherlands improves gatekeepers' knowledge of suicide prevention and their confidence to discuss suicidality, an observational study. BMC Public Health, 18(1). https://doi.org/10.1186/s12889-018-5512-8

Wang, S. M., Chou, Y. C., Yeh, M. Y., Chen, C. H., \& Tzeng, W. C. (2013). Factors associated with quality of life after attempted suicide: a cross-sectional study. Journal of Clinical Nursing, 22(15-16). https://doi.org/10.1111/jocn.12148

World Health Organization (WHO). (2012). Plan of Action about Mental Health 2013-2020 (p. 50). Geneva: World Health Organization.

Retrieved from: 
http://apps.who.int/iris/bitstream/10665/97488/1/9789243506029_spa.pdf

WHO. (2014). Preventing Suicide: A Global Imperative. Retrieved from http://apps.who.int/iris/bitstream/10665/131056/1/9789241564779

WHO. (2018). Suicide prevention. Geneva: World Health Organization. Retrieved, November 04, 2019 from https://www.who.int/health-topics/suicide\#tab=tab_1

WHO. (2020). The Global Health Observatory. Mental Health. Retrieved from https://www.who.int/data/gho/data/themes/mental-health

Yip, P. S. F., Law, C. K., Fu, K. W., Law, Y. W., Wong, P. W., \& Xu, Y. (2010). Restricting the means of suicide by charcoal burning. British Journal of Psychiatry, 196(3), 241-242. https://doi.org/10.1192/bjp.bp.109.065185

\section{Copyrights}

Copyright for this article is retained by the author(s), with first publication rights granted to the journal.

This is an open-access article distributed under the terms and conditions of the Creative Commons Attribution license (http://creativecommons.org/licenses/by/4.0/). 